\title{
PENGARUH EKSTRAK CHANNA STRIATUS TERHADAP KADAR DHA SERUM DAN NIHSS PASIEN STROKE ISKEMIK AKUT
}

\author{
THE EFFECT OF CHANNA STRIATUS EXTRACT ON DHA SERUM LEVELS \\ AND NIHSS IN ACUTE ISCHEMIC STROKE PATIENTS
}

Kundha Deyanningtyas, ${ }^{*}$ Retnaningsih, ${ }^{* *}$ Amin Husni**

\begin{abstract}
Introduction: The level of docosahexanoic acid (DHA) is associated with clinical outcome in acute ischemic stroke (AIS). Channa striatus/snakehead fish has a neuroprotective function due to its DHA content.

Aims: Investigate the effect of Channa Striatus extract (EIG) administration which contains DHA on DHA serum levels and neurological clinical output of AIS patients.

Methods: This was a randomized pre-posttest control group design with double-blind study. Patients were divided into two groups: treatment, with additional 15 grams EIG administered for 7 days, and control, without additional EIG. DHA serum levels and NIHSS scores were measured before and after treatment. Other factors that may affected the outcome were also analyzed by multivariate statistic.

Result: A total of 42 subjects were allocated randomly as treatment or control. The difference of elevated DHA serum levels in treatment group was significantly greater than control group. There was a negative correlation between DHA serum levels changes and NIHSS changes. Multivariate analysis showed that NIHSS improvement was affected by EIG (Odds ratio/OD:0.25) gender (OR:5.64).

Discussions: There was a significant relationship between EIG supplementation with NIHSS changes. EIG may improve neurologic clinical outcome a one-fourth times greater than placebo, thus can be considered as supportive treatment in the recovery of acute ischemic stroke patients.
\end{abstract}

Keywords: Channa Striatus, docosahexaenoic acid (DHA), ischemic stroke, NIHSS

\section{ABSTRAK}

Pendahuluan: Kadar docosahexanoic acid (DHA) berkaitan dengan luaran klinis stroke iskemik akut (SIA). Channa Striatus/ikan gabus mempunyai fungsi neuroprotektif karena memiliki kandungan DHA.

Tujuan: Mengetahui pengaruh pemberian ekstrak ikan gabus (EIG) yang mengandung DHA terhadap kadar DHA serum serta luaran klinis pasien stroke iskemik akut.

Metode: Penelitian dengan desain randomized pre-posttest control group secara tersamar ganda. Pasien dibagi menjadi 2 kelompok; kelompok perlakuan mendapatkan EIG 15gr selama 7 hari dan kelompok kontrol tanpa perlakuan tambahan. Kadar DHA serum dan skor NIHSS diukur sebelum dan sesudah perlakuan. Faktor-faktor lain yang berpengaruh pada luaran klinis juga dianalisis secara multivariat.

Hasil: Sebanyak 42 subjek dilakukan random alokasi sebagai kelompok perlakuan atau kontrol. Didapatkan adanya selisih peningkatan kadar DHA serum pada kelompok perlakuan yang lebih besar secara bermakna dibanding kelompok kontrol. Terdapat korelasi negatif antara perubahan kadar DHA serum dengan perubahan skor NIHSS. Analisis multivariat tampak bahwa EIG berpengaruh pada penurunan skor NIHSS (rasio Odds/RO:0,25) dan variabel jenis kelamin (RO:5,64).

Diskusi: Terdapat hubungan yang bermakna antara pemberian EIG dengan perubahan skor NIHSS pasien stroke iskemik akut. Pemberian EIG dapat memperbaiki luaran klinis neurologis seperempat kali lebih besar dibanding plasebo, sehingga dapat dipertimbangkan untuk penunjang pemulihan pasien stroke iskemik akut.

Kata kunci: Channa Striatus, docosahexaenoic acid (DHA), NIHSS, stroke iskemik

*Bagian Ilmu Penyakit Saraf FK Universitas Diponegoro/RSUP Dr. Kariadi, Semarang. Korespondensi: dr.deya.neuro@gmail.com.

\section{PENDAHULUAN}

Stroke adalah penyebab morbiditas dan mortalitas, merupakan penyebab kematian ketiga terbanyak di dunia setelah penyakit jantung koroner dan kanker, serta penyebab kecacatan jangka panjang nomor satu di dunia. Pengembangan terapi yang aman dan efektif untuk melindungi otak setelah stroke, merupakan proses yang dikenal sebagai neuroproteksi adalah tantangan besar yang belum banyak terpecahkan. Istilah neuroproteksi mengarah kepada mekanisme di dalam sistem saraf yang melindungi sel saraf (neuron) dari apoptosis atau degenerasi. ${ }^{1-2}$

Selama ini terdapat kontroversi mengenai peran makanan berlemak terhadap risiko berbagai penyakit. Namun sebenarnya minyak yang mengandung asam lemak tak jenuh ganda polyunsaturated fatty 
acid (PUFA) diakui dapat menurunkan kolesterol darah serta meningkatkan nilai kesehatan lainnya. ${ }^{1-3}$ Terdapat dua jenis asam lemak tak jenuh yang esensial untuk tubuh, yaitu asam linoleat (omega-6) dan asam linolenat (omega-3), karena dibutuhkan oleh tubuh, namun tidak dapat disintesis oleh tubuh..$^{3-7}$

Manfaat asam lemak omega-3 pertama kali ditemukan tiga dekade yang lalu, berdasarkan observasi terhadap penduduk asli Greenland Eskimo yang memiliki angka insidens penyakit jantung yang rendah walaupun mengkonsumsi makanan dengan energi, lemak, dan kolesterol tinggi. Makanan utama mereka ikan laut yang banyak mengandung lemak omega-3, terutama Docosahexaenoic Acid (DHA) dan Eicosapentaenoic Acid (EPA). ${ }^{8}$ Ikan gabus atau Channa Striatus (C. Striatus) mempunyai kandungan asam lemak tak jenuh ganda, antara lain DHA dan EPA yang terbukti mengurangi risiko kardioserebrovaskuler. ${ }^{7-8}$

Omega-3 PUFA dan DHA mempunyai fungsi neuroprotektan pada percobaan tikus ysng dilakukan oklusi arteri serebri media. Pada keadaan iskemik tersebut, omega-3 PUFA memproduksi 4-hydroxy2E-hexenal (4HHE) dan menginduksi nuclear factor E2-related factor 2 (Nrf2)/heme oxygenase-1 (HO1) sebagai antiinflamasi. Sementara DHA diberikan rata-rata 2-3 jam setelah onset dan dilakukan evaluasi luaran pada 3 jam-28 hari kemudian..$^{8-14}$

Peran DHA adalah sebagai prekursor neuroprotectin D1 (NPD1). Penelitian menyebutkan terapi DHA pada waktu 3, 4, 5, 6, sampai 7 jam setelah onset pada tikus yang diinduksi oklusi arteri serebri media dan dievaluasi pada hari ke-7, menunjukkan reduksi volume infark. ${ }^{15-21}$.

Neuroprotectin D1 berfungsi menghambat inflamasi, menghambat apoptosis dan kerusakan sel, inhibisi protein pro-apoptosis, menghambat infiltrasi leukosit, mereduksi volume infark dan edema, serta meningkatkan neurogenesis. ${ }^{17,9,11-12,14,17-18-22}$ Ikan gabus mempunyai kadar DHA yang tinggi, dapat mengurangi risiko kardiovaskular sebesar $36 \% .{ }^{22}$

\section{TUJUAN}

Untuk mengetahui pengaruh pemberian ekstrak ikan gabus/C. Striatus (EIG) yang mengandung DHA terhadap kadar DHA serum serta luaran klinis neurologis pasien stroke iskemik akut.

\section{METODE}

Penelitian dilakukan dengan desain randomized pre-posttest control group secara tersamar ganda, yaitu subjek penelitian dan pengamat, di luar dari peneliti tidak mengetahui kelompok kontrol atau perlakuan. Sampel adalah pasien stroke iskemik akut yang dirawat di RSUP Dr. Kariadi, Semarang, pada bulan Januari-Maret 2017. Kriteria inklusi adalah pasien berusia $\geq 18$ tahun stroke iskemik pertama kali, akut dengan awitan kurang dari 48 jam yang dibuktikan dengan pemeriksaan CT scan kepala, dan memiliki skor NIHSS $\geq 4$. Adapun kriteria eksklusi berupa pasien dengan gagal ginjal akut atau kronik (kadar kreatinin serum $>2,0 \mathrm{mg} / \mathrm{dL}$ ), riwayat reaksi alergi terhadap ikan, atau dengan infeksi kronik.

Subjek penelitian yang masuk dalam kriteria inklusi diberi nomer kode untuk dilakukan random alokasi, diminta bukti persetujuan secara tertulis dengan informed consent. Subjek dilakukan anamnesis menggunakan kuesioner, penilaian skor National Institutes of Health Stroke Scale (NIHSS), dan pengambilan darah vena sebanyak $5 \mathrm{cc}$ saat predan pasca-tes. Darah disimpan dalam tabung lalu disentrifuge dan diambil serumnya. Serum disimpan dalam deep freeze dan diberi nomor kode sesuai pasien. Pemeriksaan kadar DHA serum dilakukan dengan metode enzyme-linked immunosorbent assay (ELISA) di laboratorium kimia darah GAKI Fakultas Kedokteran Universitas Diponegoro, Semarang. Pemantauan luaran klinis dengan NIHSS pada hari pertama dan hari 14.

Ekstrak C. Striatus adalah dalam bentuk bubuk yang digunakan sudah diuji di laboratorium uji Bioteknologi Lembaga Ilmu Pengetahuan Indonesia (LIPI). Perlakuan berupa pemberian $60 \mathrm{~mL}$ larutan ekstrak C. Striatus yang mengandung $5 \mathrm{gr}$ ekstrak C. Striatus pada kelompok kasus setiap 8 jam selama 7 hari pertama perawatan. ${ }^{23}$

Data dianalisis bivariat dengan uji $\mathrm{T}$ berpasangan untuk melihat hubungan antara variabel perantara dengan variabel terikat serta antara variabel perancu dengan variabel terikat. Dilakukan analisis multivariat bila ada variabel uji bivariat yang memiliki nilai $\mathrm{p}<0,25$ [pengukur luaran klinis neurologis (skor NIHSS) dan analisis laboratorium]. 


\section{HASIL}

Penelitian ini melibatkan 42 subjek pasien stroke iskemik akut yang dikelompokkan secara random alokasi menjadi kelompok perlakuan dan kelompok kontrol, yang masing-masing terdiri atas 21 subjek (Tabel 1). Mayoritas subjek kelompok perlakuan adalah perempuan, sedangkan pada kelompok kontrol adalah laki-laki, namun hal ini tidak berbeda bermakna $(p=0,06)$.

Sebagian besar subjek penelitian pada kelompok perlakuan (45,7\%) maupun kelompok kontrol (54,3\%) berusia tahun $\leq 65$ tahun. Kategori indeks massa tubuh (IMT) $\geq 25$ lebih banyak dijumpai pada kelompok perlakuan (90\%), sedangkan pada kelompok kontrol lebih banyak subjek dengan IMT $<25$ (62,5\%). Hasil uji statistik kategori IMT antara kelompok perlakuan dengan kontrol berbeda bermakna $(p=0,004)$.

Tabel 1. Karakteristik Subjek Penelitian $(n=42)$

\begin{tabular}{|c|c|c|c|}
\hline \multirow[b]{2}{*}{ Karakteristik } & \multicolumn{2}{|c|}{ Kelompok } & \multirow[b]{2}{*}{$\mathbf{p}$} \\
\hline & $\begin{array}{c}\text { Perlakuan } \\
(n=21)\end{array}$ & $\begin{array}{c}\text { Kontrol } \\
(n=21)\end{array}$ & \\
\hline \multicolumn{4}{|l|}{ Jenis kelamin } \\
\hline - Laki-laki & $7(35 \%)$ & $13(65 \%)$ & $0,06^{*}$ \\
\hline - Perempuan & $14(63,6 \%)$ & $8(36,4 \%)$ & \\
\hline \multicolumn{4}{|l|}{ Umur (tahun) } \\
\hline$\cdot>65$ & $5(71,4 \%)$ & $2(29,5 \%)$ & $0,41^{\S}$ \\
\hline$\bullet \leq 65$ & $16(45,7 \%)$ & $19(54,3 \%)$ & \\
\hline \multicolumn{4}{|l|}{ IMT } \\
\hline$\bullet \geq 25$ & $9(90 \%)$ & $1(10 \%)$ & $0,004 *$ \\
\hline$\bullet<25$ & $12(37,5 \%)$ & $20(62,5 \%)$ & \\
\hline \multicolumn{4}{|l|}{ Hipertensi } \\
\hline • Ya & $20(54,1 \%)$ & $17(45,9 \%)$ & $0,34^{\S}$ \\
\hline - Tidak & $1(20 \%)$ & $4(80 \%)$ & \\
\hline \multicolumn{4}{|l|}{ Dislipidemia } \\
\hline - Ya & $1(20 \%)$ & $4(80 \%)$ & $0,34^{\S}$ \\
\hline - Tidak & $20(54,1 \%)$ & $17(45,9 \%)$ & \\
\hline \multicolumn{4}{|l|}{$\begin{array}{l}\text { Diabetes } \\
\text { melitus }\end{array}$} \\
\hline - Ada & $9(64,3 \%)$ & $5(35,7 \%)$ & $0,19 *$ \\
\hline - Tidak ada & $12(42,9 \%)$ & $16(57,1 \%)$ & \\
\hline \multicolumn{4}{|l|}{ Merokok } \\
\hline - Ada & $2(66,7 \%)$ & $1(33,3 \%)$ & $1,00^{\S}$ \\
\hline - Tidak ada & $19(48,7 \%)$ & $20(51,3 \%)$ & \\
\hline
\end{tabular}

Uji t-tidak berpasangan; *Uji $\chi^{2}$; ${ }^{\S}$ uji Fisher-exact; IMT: indeks massa tubuh.
Rerata kadar DHA serum hari pertama (Tabel 2) pada kelompok perlakuan lebih rendah dari kelompok kontrol yang meningkat lebih tinggi saat hari ke-7 secara bermakna $(p=0,043$ dan $p=0,045)$. Demikian pula tampak selisih peningkatan kadar DHA serum pada kelompok perlakuan lebih besar yang signifikan dibanding kelompok kontrol $(\mathrm{p}=0,001)$.

Tabel 3 menunjukkan tidak adanya perbedaan skor NIHSS pada hari pertama dan ketujuh pada kedua kelompok. Namun tampak selisih peningkatan skor NIHSS pada kelompok perlakuan lebih rendah secara bermakna dibanding kelompok kontrol $(\mathrm{p}=0,007)($ Tabel 4).

Pada uji korelasi Spearman terdapat korelasi negatif antara perubahan kadar DHA serum dengan perubahan skor NIHSS $(p=0,006)$. Analisis multivariat menunjukkan bahwa variabel yang berpengaruh terhadap perbaikan skor NIHSS pasien stroke iskemik akut adalah perlakuan pemberian EIG dan jenis kelamin laki-laki, dengan kekuatan hubungan yaitu pemberian EIG (rasio Odds/ $\mathrm{RO}=0,25)$, dan jenis kelamin laki-laki $(\mathrm{RO}=5,6)$. Pemberian EIG berpengaruh terhadap perbaikan skor NIHSS pasien stroke iskemik akut (Tabel 5).

\section{PEMBAHASAN}

Subjek penelitian ini memiliki proporsi perempuan lebih banyak daripada laki-laki pada kelompok perlakuan dan kontrol, serta berusia $\leq 65$ tahun. Penelitian Framingham menunjukkan bahwa tidak terdapat perbedaan insidens stroke iskemik antara laki-laki maupun perempuan pada usia 55-64 tahun. $^{24}$

Rerata kadar DHA serum hari 1 pada kelompok perlakuan adalah 101,60 (26,86-162,08)pg/ml, lebih rendah dari kelompok kontrol, yaitu 123,42 (57,17$285,51) \mathrm{pg} / \mathrm{ml}$, secara bermakna $(\mathrm{p}=0,043)$. Demikian pula kadar DHA serum saat hari ke 7 pada kelompok perlakuan lebih tinggi bermakna dibandingkan kontrol $(\mathrm{p}=0,045)$. Hal ini menunjukkan selisih peningkatan kadar DHA serum pada kelompok perlakuan lebih besar secara bermakna dibanding kelompok kontrol $(p=0,001)$.

Pada uji korelasi Spearman terdapat korelasi negatif antara perubahan kadar DHA serum dengan perubahan skor NIHSS $(\mathrm{p}=0,006)$. Analisis multivariat 
Tabel 2. Kadar DHA Serum Sebelum dan Sesudah Perlakuan $(n=42)$

\begin{tabular}{lccc}
\hline \multirow{2}{*}{ Waktu } & \multicolumn{2}{c}{ Kadar DHA } & \multirow{2}{*}{$\mathbf{p}^{¥}$} \\
\cline { 2 - 3 } & Kelompok Perlakuan & Kelompok Kontrol & 0,043 \\
\hline Hari 1 (sebelum) & $101,60(26,86-162,08)$ & $123,42(57,17-285,51)$ & 0,045 \\
Hari 7 (sesudah) & $133,14(69,34-245,22)$ & $113,57(67,83-231,44)$ & 0,001 \\
$\Delta$ DHA serum & $33,90(6,78-150,92)$ & $-14,11(-142,24-73,11)$ & 0 \\
\hline
\end{tabular}

${ }^{*}$ Uji Mann-Whitney; DHA: docosahexanoic acid.

Tabel 3. Skor NIHSS Subjek Penelitian $(n=42)$

\begin{tabular}{|c|c|c|c|}
\hline \multirow[b]{2}{*}{ Waktu } & \multicolumn{2}{|c|}{ Skor NIHSS } & \multirow[b]{2}{*}{$\mathbf{p}^{\ddagger}$} \\
\hline & $\begin{array}{l}\text { Kelompok } \\
\text { Perlakuan }\end{array}$ & $\begin{array}{c}\text { Kelompok } \\
\text { Kontrol }\end{array}$ & \\
\hline Hari 1 (sebelum) & $9(2-15)$ & $7(2-19)$ & 0,363 \\
\hline Hari 7 (sesudah) & $4(0-11)$ & $3(1-16)$ & 0,990 \\
\hline$\Delta$ NIHSS & $-4[-9-(-1)]$ & $-2(-7-0)$ & 0,007 \\
\hline
\end{tabular}

${ }^{¥}$ Uji Mann-Whitney; NIHSS: National Institutes of Health Stroke Scales.

Tabel 4. Perbedaan Perubahan skor NIHSS pada Kedua Kelompok $(n=42)$

\begin{tabular}{lcccc}
\hline \multirow{2}{*}{ Kelompok } & \multicolumn{2}{c}{ Perubahan skor NIHSS } & & Tidak \\
\cline { 2 - 3 } & $\begin{array}{c}\text { Perbaikan } \\
\text { Perlakuan }\end{array}$ & Perbaikan & & p \\
\hline Kontrol & $16(38,1 \%)$ & $13(61,9 \%)$ & 6,22 & $0,01^{*}$ \\
\hline
\end{tabular}

*Uji $\chi^{2}$; NIHSS: National Institutes of Health Stroke Scales.

menunjukkan bahwa variabel yang berpengaruh terhadap perbaikan skor NIHSS pasien stroke iskemik akut adalah perlakuan pemberian EIG dan jenis kelamin laki-laki, dengan kekuatan hubungan yaitu pemberian EIG $(\mathrm{RO}=0,25)$ dan jenis kelamin laki-laki $(\mathrm{RO}=5,6)$. Jadi pemberian EIG berpengaruh terhadap perbaikan skor NIHSS pasien stroke iskemik akut.
Penelitian Retnaningsih tentang pengaruh suplementasi EIG terhadap status protein, antioksidan, dan stres oksidatif serta luaran klinis pada stroke iskemik akut menunjukkan hasil yang positif. Hasil penelitian tersebut menunjukkan bahwa suplementasi EIG dapat memperbaiki luaran klinis yang lebih baik pada kelompok pasien stroke iskemik akut yang diukur pada hari ke $7 .^{22}$

Zhang mendapatkan tikus yang diberi suplementasi dengan omega 3 PUFA dan DHA mengalami peningkatan omega 3 dan DHA secara signifikan pada otak, mereduksi kerusakan otak, dan meningkatkan luaran neurologis jangka panjang sampai 5 minggu setelah injury. Efek neuroprotektif dari DHA juga diobservasi selama fase akut stroke iskemik dalam 24 jam sampai 7 hari setelah injury. ${ }^{25}$

Penelitian $\mathrm{Bu}$ dan Chang mengungkapkan bahwa terapi kombinasi DHA dan suplementasi diet omega 3 PUFA secara signifikan mereduksi jaringan atrofi, meningkatkan fungsi kognitif, meningkatkan neurogenesis dan angiogenesis post stroke. DHA diberikan rata-rata 2-3 jam setelah onset dan evaluasi luaran klinis pada 3 jam-28 hari, memberikan hasil luaran klinis neurologis yang lebih baik. ${ }^{21}$

Tabel 5. Analisis Multivariat Faktor-faktor yang Berhubungan dengan Perubahan NIHSS (n=42)

\begin{tabular}{|c|c|c|c|c|c|}
\hline \multirow{2}{*}{ Variabel Perancu } & \multicolumn{2}{|c|}{ Perubahan Skor NIHSS } & \multirow{2}{*}{$\mathbf{p}$} & \multicolumn{2}{|c|}{ IK 95\% } \\
\hline & Tidak Ada Perbaikan & Perbaikan & & Min & Maks \\
\hline \multicolumn{6}{|l|}{ Kelompok } \\
\hline - Perlakuan & $8(38,1 \%)$ & $13(61,9 \%)$ & $0,059 *$ & 0,06 & 1,05 \\
\hline - Kontrol & $16(76,2 \%)$ & $5(23,8 \%)$ & & & \\
\hline \multicolumn{6}{|l|}{ Usia (tahun) } \\
\hline - $>65$ & $2(28,6 \%)$ & $5(71,4 \%)$ & $0,297 \S$ & 0,04 & 2,59 \\
\hline - $\leq 65$ & $22(62,9 \%)$ & $13(37,1 \%)$ & & & \\
\hline \multicolumn{6}{|l|}{ Jenis kelamin } \\
\hline - Laki-laki & $16(80,0 \%)$ & $4(20,0 \%)$ & $0,021 *$ & 1,31 & 24,4 \\
\hline - Perempuan & $8(36,4 \%)$ & $14(63,6 \%)$ & & & \\
\hline
\end{tabular}


Penelitian ini sesuai dengan Kim dkk yang menyatakan bahwa risiko aterosklerosis berkorelasi dengan level DHA dan EPA pada fosfolipid $(\mathrm{RO}=0,590$, IK 95\% 0,35; $\mathrm{p}<0,05)$, mengindikasikan bahwa risiko meningkat apabila level DHA rendah. ${ }^{22}$

Keterbatasan penelitian ini adalah tidak dilakukan pemeriksaan variabel lain yang terlibat dan memengaruhi luaran klinis stroke iskemik akut yang terkait dengan inflamasi, tidak dilakukan pemeriksaan letak lesi dan tipe lesi-lesi yang memengaruhi luaran klinis pasien stroke iskemik akut, serta tidak dilakukan pemeriksaan food recall dietary, sehingga tidak diketahui asupan makanan pasien yang dapat memengaruhi kadar DHA.

\section{KESIMPULAN}

Terdapat hubungan yang bermakna antara pemberian EIG dengan peningkatan kadar DHA serum pasien stroke iskemik akut dan perubahan skor NIHSS pasien stroke iskemik akut. Pemberian EIG dapat memperbaiki luaran klinis neurologis seperempat kali lebih besar dibanding plasebo pada pasien stroke iskemik akut, adapun pasien stroke iskemik akut dengan jenis kelamin laki-laki memiliki kemungkinan perbaikan luaran klinis sebesar 5,6 kali dibanding perempuan.

\section{DAFTAR PUSTAKA}

1. Dyall SC. Long-chain omega-3 fatty acids and the brain: a review of the independent and shared effects of EPA, DPA and DHA. Front Aging Neurosci. 2015;7:1-15.

2. Theobald HE, Chowienczyk PJ, Whittall R, Humphries SE, Sanders TAB. LDL cholesterolraising effect of low-dose docosahexaenoic acid in middle-aged men and women 1-3. Am J Clin Nutr. 2004;79(4):558-63.

3. Stark KD, Van Elswyk ME, Higgins MR, Weatherford CA, Salem N. Global Survey of the omega 3 fatty acids, docosahexaenoic and eicosapentaenoic acid in the blood stream of healthy adults. Prog Lipid Res. 2016;63:132-52.

4. Panagan AT, Yohandini H, Wulandari M. Analisis kualitatif dan kuantitatif asam lemak tak jenuh omega-3, omega-6 dan karakterisasi minyak ikan patin (pangasius pangasius). J Penelit Sains. 2012;15:2-6.

5. Davidson HM. Omega-3 fatty acids: new insights into the pharmacology and biology of docosahexaenoic acid, docosapentaenoic acid, and eicosapentaenoic acid. Curr Opin Lipidol. 2013;24(6):467-74.
6. Budimarwanti. Analisis lipida sederhana dan lipida kompleks. Staff Site Universitas Negeri: Yogyakarta; 2014. h. 1-12.

7. Asfar M, Tawali AB, Abdullah N, Mahendradatta M. Extraction of albumin of snakehead fish (Channa striatus) in producing the fish protein concentrate (FPC). IJSTR. 2014;3(4):85-8.

8. Nichols PD, Petrie J, Singh S. Long-chain omega-3 oils-an update on sustainable sources. Nutrients. 2010;2(6):572-85

9. Calder PC. Marine omega-3 fatty acids and inflammatory processes: effects, 3 mechanisms and clinical relevance. Biochim Biophys Acta. 2015;1851(4)469-84.

10. Paterniti I, Impellizzeri D, Di Paola R, Esposito E, Gladman S, Yip P, dkk. Docosahexaenoic acid attenuates the early inflammatory response following spinal cord injury in mice: in-vivo and in-vitro studies. J Neuroinflammation. 2014;11(1):6.

11. Michael-Titus AT, Priestley JV. Omega-3 fatty acids and traumatic neurological injury: from neuroprotection to neuroplasticity? Trends Neurosci. 2014;37(1):30-8.

12. Begum G, Yan HQ, Li L, Singh A, Dixon CE, Sun D, Docosahexaenoic acid reduces er stress and abnormal protein accumulation and improves neuronal function following traumatic brain injury. J Neurosci. 2014;34(10):3743-55.

13. Hong SH, Belayev L, Khoutorova L, Obenaus A, Bazan NG. Docosahexaenoic acid confers enduring neuroprotection in experimental stroke. J Neurol Sci. 2014;338(1-2):135-41.

14. Belayev L, Khoutorova L, Hong SH, Obenaus A. A novel therapeutic strategy for experimental stroke using docosahexaenoic acid complexed to human albumin. OCL. 2016;23(1):D109.

15. Bu J, Dou Y, Tian X, Wang Z, Chen G. The role of omega-3 polyunsaturated fatty acids in stroke. Hindawi Publ Corp. 2016;2016:6906712.

16. Chang C, Kuan Y, Li J, Chen W, Ou Y, Pan H, dkk. Science direct docosahexaenoic acid reduces cellular inflammatory response following permanent focal cerebral ischemia in rats. J Nutr Biochem. 2013;24(12):2127-37.

17. Pu H, Jiang $\mathrm{X}, \mathrm{Hu} \mathrm{X}$, Xia J, Hong D. Delayed docosahexaenoic acid treatment combined with dietary supplementation of omega-3 fatty acids promotes long-term neurovascular restoration after ischemic stroke. Transl Stroke Res. 2016;7(6):52134.

18. Chauveau F, Cho TH, Perez M, Guichardant M, Riou A, Aguettaz P, dkk. Brain-targeting form of docosahexaenoic acid for experimental stroke 
treatment: MRI evaluation and anti-oxidant impact. Curr Neurovasck Res. 2011;8(2):95-102.

19. Yang Y, Lii C, Wei Y, Li C, Lu C, Liu K, dkk. Docosahexaenoic acid inhibition of inflammation is partially via cross-talk between Nrf2/heme oxygenase 1 and IKK/NF-א B pathways. J Nutr Biochem. 2013;24(1):204-12.

20. Singhal A, Lanigan J, Storry C, Low S, Birbara T, Lucas A, dkk. Docosahexaenoic acid supplementation, vascular function and risk factors for cardiovascular disease: a randomized controlled trial in young adult. AHA Journal. 2013;2(4):e000283.

21. Bazan NG. Basic neurochemistry: molecular, cellular, and medical aspects. brain ischemia and reperfusion: cellular and molecular mechanism in stroke injury. Am Soc Neurochem. 2016;8:621-42.
22. Retnaningsih. Pengaruh suplementasi ekstrak ikan gabus terhadap status protein, status antioksidan dan status oksidatif pada pasien stroke iskemik akut [disertasi]. Semarang: Universitas Diponegoro; 2013.

23. Laboratorium Uji Bioteknologi. Laporan hasil uji kandungan Vipalbumin (ekstrak ikan gabus). Lembaga Ilmu Pengetahuan Indonesia. 2009.

24. Zhang M, Wang S, Mao L, Leak RK, Shi Y, Zhang $\mathrm{W}$, dkk. Omega-3 fatty acids protect the brain against ischemic injury by activating $\mathrm{Nrf} 2$ and upregulating heme oxygenase 1. J Neurosci. 2014;34(5):1903-15.

25. Gibson CL. Cerebral ischemic stroke: is gender important? J Cereb Blood Flow Metab. 2013;33 (9):1355-61. 